\title{
Grafting Bell Peppers an Alternative for Growers
}

\author{
Marian BOGOESCU*, Madalina DOLTU, Dorin SORA, Bogdan IORDACHE \\ Institute of Research and Development for Industrialization and Marketing of Horticultural Products, \\ Drumul Gilăului, no.5N, sector 4, Bucureşti, 041715 \\ *corresponding author: bogoescumarian@gmail.com
}

BulletinUASVM Horticulture 76(1) / 2019

Print ISSN 1843-5254, Electronic ISSN 1843-5394

DOI:10.15835/buasvmcn-hort: 2018.0026

\begin{abstract}
Crop rotation is rarely practiced in greenhouse production, which allows soil borne pathogens and pests to accumulate, progressively reducing crop yields and fruit quality. Grafting cultivars with high quality and productivity on rootstocks that are resistant to the soil pests and diseases is a method known from years ago, which was improved and quickly spread in the last years. The aim of this research was to evaluate the performance of the grafted peppers on some rootstocks, in greenhouse conditions. Marketable yield, fruit quality and nutritional qualities (total soluble solid contents, titratable acidity, soluble carbohydrates, Vitamin C content) have been determined. The marketable yield and fruit number were positively influenced by rootstock as compared with ungrafted peppers. The obtained results showed that grafting has improved the commercial quality of pepper fruits. There were no significant differences in the nutritional qualities of pepper fruits obtained from the grafted or ungrafted plants.
\end{abstract}

Keywords: quality, pepper yield, nutritional qualities, scion, ungrafted

\section{Introduction}

In field production, crop rotation is important to prevent infestation with diseases and pests. However, crop rotation is rarely practiced in greenhouse production, which allows soil borne pathogens and pests to accumulate, progressively reducing crop yields and fruit quality.

Productive and high qualitative pepper cultivars grafted onto rootstocks that are resistant to soil pests and diseases were obtained some time ago and have spread quickly.

Joining a suitable cultivar scion to a wild-type rootstock which has a robust root system and strong resistance to soil pests and diseases induce the tolerance features to less favorable conditions of soil and environment (Oda, 1993; Edelstein, 2004).

Some greenhouse pepper growers demonstrate the main result of the grafting process, which was the increase of resistance against soil diseases such as Fusarium, Verticillium or nematodes and increase the productivity and quality of the pepper fruits; Likewise, more yield and larger fruits were reported in grafted peppers (Gisbert et al., 2010).

Flores et al. (2010) reported that the soluble solid content and titratable acidity of fruits were improved by grafting. Fernández et al. (2013) refer to the modifications of fruit shape index and also Colla et al, (2008) reported modifications of plant vigor. Changes related to the vitamin $\mathrm{C}$ content in grafted pepper were reported by Mendoza (2013). Grafted pepper also displays changes in nutrition and production of bioactive compounds. Grafting increases the amount of antioxidant compounds in the peppers (Mendoza et al., 2015). Changes in nutritional composition of bell peppers depend on the genotype of the combined cultivars (Sanchez et al., 2016). Volkan and Hakan (2018) mention that some of the qualities such as fruit length, fruit stem length, fruit diameter, fruit flesh diameter were not affected by grafted combination.

The aim of this research was to evaluate the performance of the commercial hybrid bell pepper 
grafted on three newly resistant pepper rootstocks in comparison with a well-known commercial rootstock and ungrafted pepper, in greenhouse conditions.

\section{Materials and methods}

Experimental plots of grafted bell peppers were organized in the first cycle in 2017, in an unheated pilot greenhouse covered by plastic film, with fertirigation system by drop and semi-automatic ventilation, at the Research and Development Institute for Processing and Marketing of Horticultural Products in Bucharest.

The pepper hybrid $\mathrm{F}_{1}$ "Menta" used as scion, was grafted onto the Romanian pepper rootstocks of perspective L-63, L-12 and "Foundation" rootstock.

The main features of the used rootstocks are:

L-12: Long pepper (Capsicum anuum var. longum) proposed as rootstock with great vigor; plant height exceeds $180 \mathrm{~cm}$ in protected areas and $90 \mathrm{~cm}$ in field; genetic resistance to the specific diseases (Fusarium oxysporum, V.M.T., Verticillium) in particular the specific soil pests and nematodes. It presents a vigorous root system, well developed; the main roots explore the deeper layers of soil up to $45 \mathrm{~cm}$ and due to his genetic characteristics it shows higher resistance to extreme environmental conditions; maturity group: 01- early.

L-63: Bell pepper (Capsicum anuum var. grossum) is a vigorous plant with a height of about $175 \mathrm{~cm}$ in protected areas and $85 \mathrm{~cm}$ in field. This genotype has large production capacity. It has good resistance to extreme environmental conditions, besides, it is tolerant to major pests and specific diseases, also to the nematodes attack; maturity group: 02 - semi early.

"Foundation" $\mathrm{F}_{1}$ : it is the first generation of rootstock specific for grafting peppers; obtained by Rijk Zwaan Company, Netherlands, as an intraspecific hybrid (Capsicum annum). The root system is very strong. It has a very good resistance to the attack of some pathogens: Tobacco mosaic virus (TM 0), Potato virus Y 0.1 and it has tolerance to the nematodes attack and Phytophthora capsici.

The main features of the used cultivars are the following: "Menta" $F_{1}$ is a blocky type pepper hybrid, released by Rijk Zwaan - Holland; both for cultivation in protected area (greenhouse, solar) and in open field; it is resistant to attack of the phytopathogenic agents: Tobacco mosaic virus 0 ,
1, 2, respectively Potato virus $Y, 0$; maturity group: 02 - semi-early, harvest period: 65-75 days after transplanting.

The researches refer to the behavior of rootstock $\times$ scion combinations in terms of average production recorded, earliness, commercial quality and nutritional value of the pepper fruits.

The following futures were determined: number of fruits/plant, fruits weight (g), average production/plant (g), average production $/ \mathrm{m}^{2}$, earliness (by quantifying the yield from planting up to first 30 days of harvest). Commercial quality was expressed in percent (\%), according to the stipulations of the Regulation (EC) no. 1221/2008, which sets the norms for the application of the Council's Regulations (EC) no. 2200/96, (EC) no. $2201 / 96$ and (EC) no. 1182/2007, regarding the marketing standards for fruit and vegetables.

Soluble dry matter (\%) was determined by the refractometric method, total carbohydrate content (\%) was determined by Bertrand method and titratable acidity (\%) by g malic acid/100g e.s.; the content of bell pepper fruits in ascorbic acid (mg/100g e.s.) was determined by the high performance liquid chromatography (HPLC), with UV detection at $254 \mathrm{~nm}$.

In appreciating the quality of a product, sensory attributes are determining issues, by which a first contact the consumer values. In order to identify any sensory changes of the bell pepper following the grafting process, a sensory analysis test was carried out on the variants obtained.

The analysis tables included three basic criteria of sensory qualities: aspect, texture, taste. Each of these three criteria had a different share in the overall grade. Thus, the aspect has a share of $15 \%$ (a coefficient of 3\%), the texture a share of 35\% (a coefficient of 7\%) and the taste a share of $50 \%$ (a coefficient of $10 \%$ ). Tests resulted in a general score that is differentiated on 5 sensory quality classes.

\section{$81-100$ very good \\ 61 - 80 good \\ 41 - 60 acceptable \\ 21 - 40 mediocre \\ 1 - 20 unsatisfactory}

Experimental variants were organized in randomized blocks, each of them consisting of three repetitions. The extent of the experimental block was of $120 \mathrm{~m}^{2}$. Each of the three repetitions of one variant had an area of $10 \mathrm{~m}^{2}$. The seedlings 
Table 1. Climatic data in unheated greenhouse, May - September 2017

\begin{tabular}{|c|c|c|c|c|c|c|c|}
\hline \multirow{2}{*}{$\begin{array}{c}\text { Calendar } \\
\text { period }\end{array}$} & \multicolumn{3}{|c|}{ Temperature $\left({ }^{\circ} \mathrm{C}\right)$} & \multicolumn{3}{|c|}{ Relative humidity (RH\%) } & \multirow{2}{*}{$\begin{array}{c}\text { Medium } \\
\text { temperature } \\
\text { in soil }\end{array}$} \\
\hline & Maximum & Minimum & Medium & Maximum & Minimum & Medium & \\
\hline 01-10 May & 26,4 & 14,8 & 19,8 & 87,9 & 23,6 & 52,7 & 19,7 \\
\hline 11-20 May & 25,4 & 13,7 & 18,4 & 90,8 & 22,9 & 53,1 & 19,1 \\
\hline 21-31 May & 27,1 & 16,5 & 21,1 & 88,4 & 23,6 & 51,9 & 21,9 \\
\hline 01-10 June & 34,4 & 18,0 & 23,1 & 90,2 & 23,7 & 52,2 & 23,1 \\
\hline 11-20 June & 28,4 & 16,0 & 21,2 & 86,3 & 21,4 & 49,8 & 22,7 \\
\hline 21-30 June & 34,9 & 18,3 & 26,8 & 84,7 & 23,6 & 53,3 & 23,5 \\
\hline 01-10 July & 32,4 & 18,5 & 26,1 & 88,0 & 24,0 & 61,0 & 22,1 \\
\hline 11- 20 July & 33,5 & 17,9 & 28,0 & 92,6 & 33,9 & 59,0 & 21,4 \\
\hline 21-31 July & 34,1 & 19,6 & 23,5 & 63,0 & 23,2 & 40,3 & 21,5 \\
\hline 01-10 August & 37,5 & 23,1 & 30,7 & 86,2 & 23,5 & 47,2 & 24,1 \\
\hline 11-20 August & 34,9 & 21,5 & 26,6 & 77,6 & 26,8 & 46,1 & 23,6 \\
\hline 21-31 August & 32,7 & 18,4 & 24,9 & 90,2 & 23,7 & 52,2 & 22,7 \\
\hline 01-10 September & 30,4 & 16,7 & 26,8 & 86,3 & 21,4 & 49,8 & 21,8 \\
\hline 11-20 September & 33,5 & 18,2 & 23,5 & 84,7 & 23,6 & 53,3 & 20,3 \\
\hline 21-30 September & 23,3 & 13,5 & 18,2 & 88,3 & 26,3 & 63,1 & 16,5 \\
\hline
\end{tabular}

were grafted by splice grafting method, which is a simple grafting technique with some disadvantages: requires careful control of relative humidity, of light intensity and temperature after grafting. Large losses can be recorded due to precarious environmental control; there is also an increased risk of developing diseases due to very high relative humidity.

The seedlings have been transplanted on May $7^{\text {th }} 2017$ and cleared on October $5^{\text {th }}, 2017$.

Temperature is one of the environmental factors for which the pepper has high requirements. The optimal temperature for growing and development is $22-25{ }^{\circ} \mathrm{C}$; the extreme limits allowed are between 15 and $35^{\circ} \mathrm{C}$. Flowering and fructification are carried out under optimum conditions at a medium temperature of air and soil of about $25^{\circ} \mathrm{C}$.

During the vegetation period, the climatic factors from the unheated greenhouse (minimum, medium and maximum temperature; minimum, medium and maximum humidity) were recorded using an electronic thermohygrometer (Testo 172-H2). Soil temperature measurement, both in the greenhouse and in the field, has been done at 8 o'clock in the morning, at a depth of $10 \mathrm{~cm}$, using a professional soil thermometer (Tab. 1).

The first harvest was obtained at 81 days after planting, even if the distributor's recommendation states that the "Menta" hybrid can be harvested at 75 days after planting. It is possible that in some scions $\times$ rootstocks combinations a phenomenon of delay occurred at the first harvest.

\section{Results and discussions}

In order to emphasize the influence of using grafted bell peppers, the marketable yield data were collected for each variant (Tab. 2). The yield varied depending of the rootstock used and the performed growing method (grafted bell pepper vs. ungrafted).

The range of variation was relatively small between grafted variants, but between variants of grafted pepper and ungrafted plants, the yield difference was statistically significant.

The rootstocks that have led to high productions were L-63 (an average of $4.446 \mathrm{~kg}$ / $\mathrm{m}^{2}$ ) and "Foundation" (an average of $4.438 \mathrm{~kg} /$ $\mathrm{m}^{2}$ ). Good results were also recorded for the L-12 lines $\left(3.910 \mathrm{~kg} / \mathrm{m}^{2}\right)$. The lowest production was recorded as expected in the ungrafted peppers $\left(3.648 \mathrm{~kg} / \mathrm{m}^{2}\right)$.

The number of fruits per plant ranged from 7 , in combinations with L-12 rootstocks, to 9, in grafted plants with L-63 rootstocks. "Foundation" rootstock and the cultivar "Menta" ungrafted had 8 fruits/plant; average fruit weight has been higher in the combination "Menta" $\times \mathrm{L}-12$, respectively 147g. The smallest fruits were observed in ungrafted "Menta" plants, respectively $120 \mathrm{~g}$. In some L-63 pepper rootstocks the greater yield obtained has been associated with higher fruit number rather than fruit weight. 
Table 2. The yield of marketable fruits of grafted peppers "Menta" $F_{1}$ as influenced by different rootstocks

\begin{tabular}{ccccc}
\hline $\begin{array}{c}\text { Variant } \\
\text { (scion } \times \text { rootstock) }\end{array}$ & Fruits/plant & $\begin{array}{c}\text { Fruit } \\
\text { weight } \\
(\mathrm{g})\end{array}$ & $\begin{array}{c}\text { Yield/ } \\
\text { plant } \\
(\mathrm{kg})\end{array}$ & $\begin{array}{c}\text { Total yield } \\
\left(\mathrm{kg} / \mathrm{m}^{2}\right)\end{array}$ \\
\hline "Menta" $\mathrm{F}_{1} \times \mathrm{L}-63$ & 9 & 130 & 1.170 & $4.446 \mathrm{a}^{*}$ \\
\hline "Menta" $\mathrm{F}_{1} \times \mathrm{L}-12$ & 7 & 147 & 1.029 & $3.910 \mathrm{ab}$ \\
\hline "Menta" $\mathrm{F}_{1} \times$ Foundation & 8 & 146 & 1.168 & $4.438 \mathrm{a}$ \\
\hline "Menta" F & 8 & 120 & 0.960 & $3.648 \mathrm{~b}$ \\
\hline The mean values noted with the same letters do not present significant difference, for $\mathrm{p}=5 \%$ &
\end{tabular}

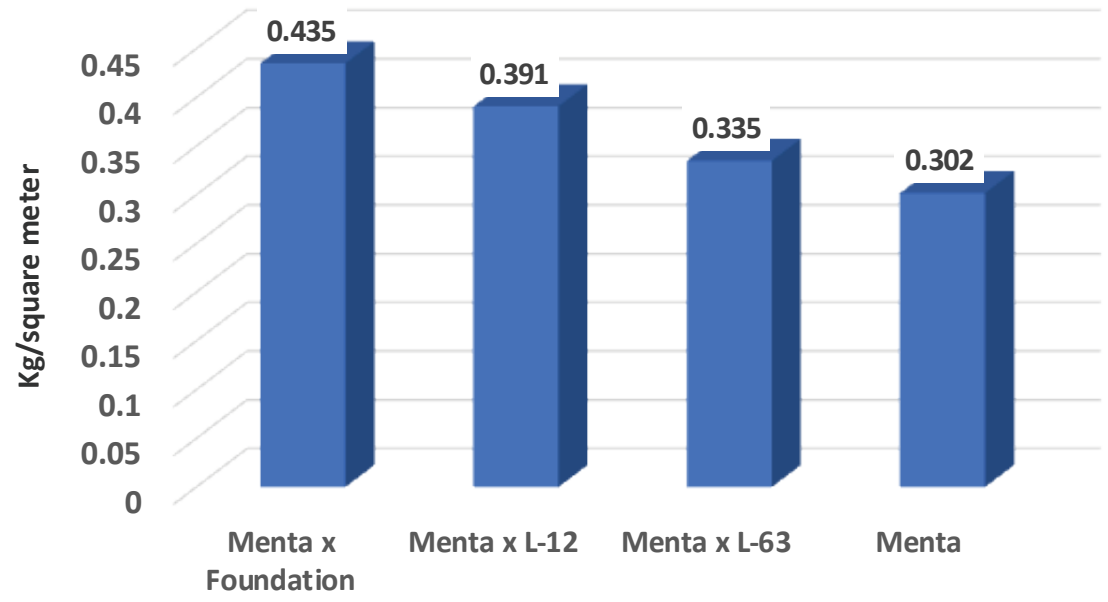

Figure 1. Effects of different rootstocks on the precocity of grafted peppers

The first harvest of the variants obtained was carried out in July 27, respective 83 days after planting the pepper seedlings.

High precocity (Fig. 1) was recorded in combinations between "Menta" × "Foundation" (an average of $0.435 \mathrm{~kg} / \mathrm{plant}$ ), "Menta" $\times \mathrm{L}-12$ (an average of $0.391 \mathrm{~kg} /$ plant) and "Menta" $\times$ L-63 (an average of $0.335 \mathrm{~kg} /$ plant).

The registered results emphasize that precocity was mainly determined by genetic characteristics of rootstock and scion, than by the grafting process.

Previous studies (Lee, 1994; Rouphael et al., 2010) have shown that grafting affects vegetable quality and the modifications can be positive or detrimental. On the other hand, cultural practices and environmental conditions may greatly influence fruit quality.

On these considerations, in Figure 2 there are presented data which refers to the influence of rootstock and grafting method on the percentage of Class I bell pepper fruits.

Fruit quality was assessed according to the Romanian standard of quality for fresh fruits and vegetables. The data analysis showed an improvement of commercial quality of grafted plants, with over $14.7 \%$ the Class I fruits quality, as compared with ungrafted peppers; the differences between grafted peppers and ungrafted plants are statistically significant.

Grafting peppers led to improving their quality. The best results were recorded at the "Foundation" rootstocks, (96\% Class I quality fruits) and L-63 (94.1\% Class I quality fruits) while a percentage of only $91 \%$ Class I quality fruits, was registered in the L-12 rootstock. Differences between the grafted plants, whatever the rootstock used, are not statistically significant. In average, the ungrafted peepers has only $82.65 \%$ Class I quality fruits.

Among the fruit quality parameters concerning nutritional value, in this work have been evaluated (Tab. 3) soluble dry matter, titratable acidity, total carbohydrate and ascorbic acid content.

Nutritional quality of the peppers was influenced by rootstocks and scion genotype, considering that the abiotic factors have been the same for all analyzed variants.

The nutritional value of peppers expressed as soluble dry matter content and titratable 


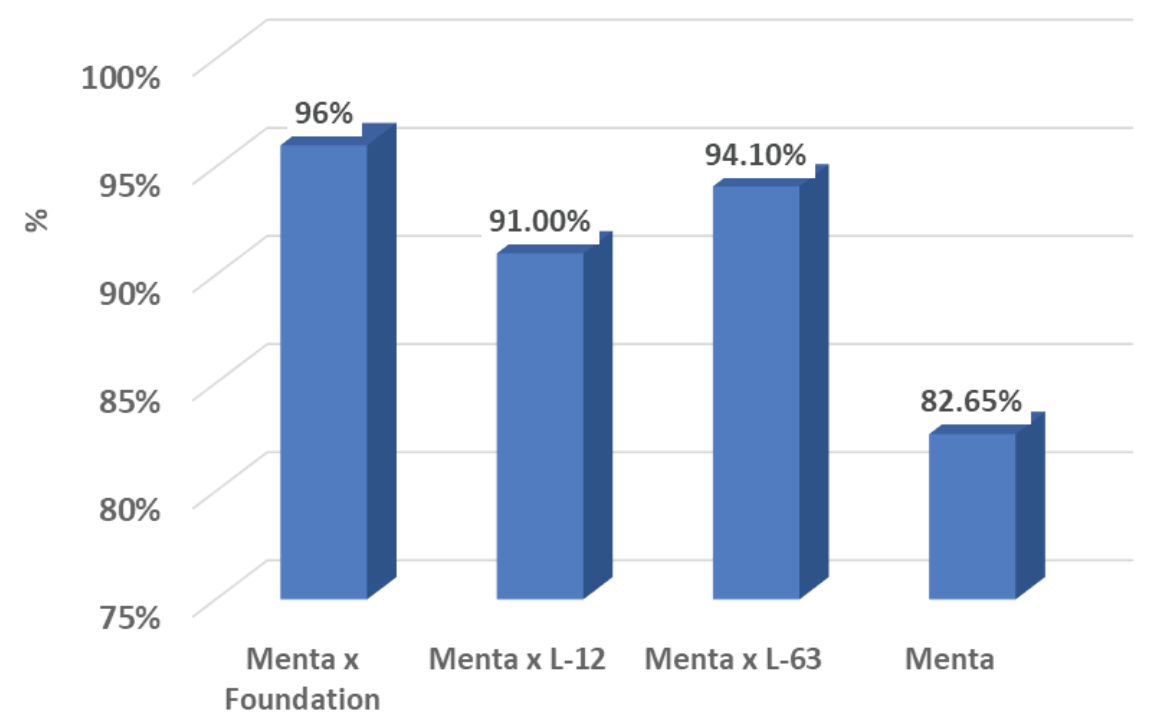

Figure 2. Effects of different rootstocks on the first quality grafted peppers fruits

Table 3. Effect of different rootstocks on the nutritional value of grafted peppers

\begin{tabular}{ccccc}
\hline $\begin{array}{c}\text { Variant } \\
\text { (Scion x Rootstock) }\end{array}$ & $\begin{array}{c}\text { Soluble dry } \\
\text { matter } \\
\left({ }^{\circ} \mathrm{R}\right)\end{array}$ & $\begin{array}{c}\text { Titratable acidity } \\
(\mathrm{g} / 100 \mathrm{~g})\end{array}$ & $\begin{array}{c}\text { Total } \\
\text { carbohydrate } \\
\text { content }(\%)\end{array}$ & $\begin{array}{c}\text { Ascorbic acid } \\
(\mathrm{mg} / 100 \mathrm{~g} \text { s.e. })\end{array}$ \\
\hline "Menta" $\mathrm{F}_{1} \times \mathrm{L}-63$ & 4.12 & 0.196 & 1.41 & 72.22 \\
\hline "Menta" $\mathrm{F}_{1} \times \mathrm{L}-12$ & 3.76 & 0.125 & 2.457 & 91.37 \\
\hline "Menta" $\mathrm{F}_{1} \times$ "Foundation & 4.56 & 0.125 & 2.052 & 96.67 \\
\hline "Menta" $\mathrm{F}_{1}$ & 3.79 & 0.121 & 1.184 & 87.41 \\
\hline
\end{tabular}

acidity have not undergo significant changes as a consequence of the grafting process.

Soluble dry matter ranged from $4.12{ }^{\circ} \mathrm{R}$ ("Menta" × "Foundation") up to $3.76^{\circ} \mathrm{R}$ ("Menta" $\times$ L-12). Among the studied rootstocks, the highest quantity of dry matter was registered in L-63 $\left(4.12^{\circ} \mathrm{R}\right)$.

Titratable acidity has been between $0.121 \mathrm{~g} / 100 \mathrm{~g}$ malic acid ("Menta" ungrafted) and $0.196 \mathrm{~g} / 100 \mathrm{~g}$ malic acid, recorded in the combination "Menta" $\times$ L-63. The range of variation was higher in total carbohydrate and ascorbic acid content. Higher amount in total carbohydrates was determined from the combination "Menta" $\times$ L-12 (2.457\%) and "Menta" × "Foundation" (2.052\%), respectively.

Ascorbic acid ranged from $96.67 \mathrm{mg} / 100 \mathrm{~g}$ in the combination "Menta" $\times$ "Foundation" up to $72.225 \mathrm{mg} / 100 \mathrm{~g}$ in "Menta" $\times$ L-63 combination.

In order to identify any changes in the pepper fruits sensorial quality as a result of the grafting process, sensorial analyzes were performed upon the studied variants. The results have shown an improvement in aspect, texture and taste of bell pepper fruits in all combinations performed compared with ungrafted cultivar (Tab. 4).

A particular aspect of fruits was registered in the L-12 rootstock combinations. Regarding the texture of the pericarp, there were not identified significant differences between the studied rootstocks and the other commercial rootstocks. The L-63 rootstocks conferred a very pleasant taste to fruits, being rated with "very good".

General appreciation of the fruits has not led to significant differences between combinations of grafted peppers, all having been qualified "very good"; the ungrafted cultivar "Menta" receiving the general qualification "good".

\section{Conclusions}

The obtained results emphasize the positive effect of grafting peppers on the average production. The range of variation was statistically significant between the variants of grafted pepper and ungrafted plants.

The results registered show that precocity has been determined by genetic characteristics 
Table 4. Effects of different rootstocks on the sensorial quality of grafted peppers

\begin{tabular}{ccccc}
\hline $\begin{array}{c}\text { Variant } \\
\text { (scion } \times \text { rootstock) }\end{array}$ & Aspect & Texture & Taste & General rating \\
\hline "Menta" $\mathrm{F}_{1} \times \mathrm{L}-63$ & 10 & 35 & 43 & $88 \mathrm{a}^{*}$ \\
& Good & Very good & Very good & Very good \\
\hline "Menta" $\mathrm{F}_{1} \times \mathrm{L}-12$ & 15 & 35 & 35 & $85 \mathrm{a}$ \\
& Very good & Very good & Good & Very good \\
\hline "Menta" $\mathrm{F}_{1} \times$ "Foundation & 10 & 35 & 36 & 81 a \\
& Acceptable & Very good & Good & Very good \\
\hline "Menta" $\mathrm{F}_{1}$ & 9 & 28 & 35 & $72 \mathrm{~b}$ \\
*The mean values noted with the same letters do not present significant difference, for $\mathrm{p}=5 \%$ & Good
\end{tabular}

of rootstock and scion, rather than the grafting process.

Grafting peppers led to improving their quality. The nutritional value of peppers expressed as soluble dry matter content and titratable acidity have not undergo significant changes in the process of grafting. The range of variation was higher in total carbohydrate and ascorbic acid content.

The sensorial quality of the fruits did not present significant differences between combinations of grafted peppers.

The difference in performance of the three rootstocks presented in this work indicates the need for careful evaluation of rootstocks for grafting in the future. The introduction of new genotypes is required so as to improve yield under a variety of biotic and abiotic conditions.

Acknowledgments. This work was supported by founding source Project ADER 337, financed by Agriculture and Rural Development Ministry.

\section{References}

1. Chávez-Mendoza C, Sánchez E, Carvajal-Millán E, MunõzMárquez E, Guevara-Aguillar A (2013). Characterization of the nutraceuticalquality and antioxidant activity in bell pepper in responseto grafting. Molecules,18: 15689-15703.

2. Chávez-Mendoza C, Sánchez E, Munõz-Márquez E, Sida-Arreola J.P, Flores-Cordova M.A (2015). Bioactive Compounds and Antioxidant Activity in Different Grafted Varieties of Bell Pepper. Antioxidants, 4(2): 427-436.

3. Colla G, Rouphael Y, Cardarelli M, Temperini O, Rea E, Salerno A (2008). Influence of grafting on yield and fruitquality of pepper (Capsicum annuum L.) grown under greenhouse conditions. Acta Horticulturae, 782: 359-36.
4. Edelstein M, Ben-Hur M (2015). Grafting: a useful tool to increase tolerance to toxic elements in vegetables under arid and semiarid conditions. Acta Horticulturae, 1086: 133-140.

5. Flores FB, Sanchez-Bel MT, Estañ MM, Martinez-Rodriguez E, Moyano B, Morales JF, Campos J O, Garcia-Abellan M I, Egea N, Fernandez-Garcia F, Romojaro M, Bolarin C (2010). The effectiveness of grafting to improve tomato fruit quality. Sci. Horticulturae, 125: 211-217.

6. Gisbert C, Sánchez-Torres P, Raigón MD, Nueza F (2010). Phytophthora capsici resistance evaluation in pepper hybrids: Agronomic performance and fruit quality of pepper grafted plants. Journal Food Agriculture Environmental, 8: 116-121.

7. Leal-Fernández C, Godoy-Hernández H, Núñez-Colín CA, Anaya-López J A, Villalobos-Reyes S, Castellanos JZ (2013). Morphological response and fruit yield of sweet pepper (Capsicum annuum L.) grafted onto different commercial rootstocks. Biological Horticulturae, 29: 1-11.

8. Lee JM (1994). Cultivation of grafted vegetables, current status, grafting methods and benefits. HortScience, 29: 235-239.

9. Oda M. (1993). Present state of vegetable production using grafted plants in Japan. Agr. Hort., 68: 442-446.

10. Paloma ST, Raigón M.D, Gammoudi N, Gisbert C (2016). Effects of Grafting Combinations on the Nutritional Composition of Pepper Fruit." Fruits, 71(4): 249-256.

11. Rouphael Y, Schwarz D, Krumbein A, Colla G (2010). Impact of grafting on product quality of fruit vegetables, Sci. Hortic. 127: 172-179.

12. Volkan E, Hakan A (2018). Effect of grafting on yield and fruit quality of pepper (Capsicum annuum L.) grown under open field conditions. Scientific Papers. Series B, Horticulture. Vol. LXII: 463 - 466. 